\title{
Challenges in implementation of Competency Based Medical Education - A Cross Sectional survey among medical faculty in India
}

sangeetha kandasamy

government medical college https://orcid.org/0000-0001-8458-512X

Dr.A.Precilla Catherine

Government Stanley Medical College \& Hospital

Shivkumar Gopalakrishnan ( $\square$ gopalakrishnanshivkumar@gmail.com )

governemnt villupuram medical college https://orcid.org/0000-0002-4933-1076

\section{Research Article}

Keywords: Competency Based Medical Education, Faculty Development Program, Indian Medical Graduate, Graduate Medical Education Regulations, Medical Education

Posted Date: July 28th, 2021

DOl: https://doi.org/10.21203/rs.3.rs-753685/v2

License: (c) (i) This work is licensed under a Creative Commons Attribution 4.0 International License. Read Full License 


\section{Abstract}

Background. In India, Competency Based Medical Education (CBME) is gaining foothold to transform the medical student into a doctor fulfilling community and societal needs. With that end in view the teaching faculty are getting sensitized and trained by the National Faculty Development Program (FDP).

Objectives. To assess the awareness about FDP among teaching faculty in medical colleges. To study the attitude \& perceived barriers to implementation of CBME.

Methods. This questionnaire based multicentric cross sectional study was conducted among teaching faculties in Indian medical institutes. Electronic media [Google forms] was used to disseminate the questionaire. Attitudinal and perceptional differences were internally compared among the faculties.

Results. Among 251 participants $90.2 \%$ faculties from private institutes had undergone FDP significantly more than those from Government sector $(p=0.008)$. We observed that $92.4 \%$ were aware, $80.2 \%$ had undergone Curriculum Implementation Support Program (CISP) and 95.2\% did agree that CBME will improve the medical education system.

Major challenges perceived were high student to faculty ratio (67.7\%), ill developed infrastructure (41.4\%) and difficulties in assessment (41.1\%). The popular solutions suggested were to increase faculty strength (73.7\%), improve infrastructure (69.3\%), extra remuneration (35.9\%) and increase administrative support (30.7\%). There were significant difference of opinions between teaching faculty of government and private sector $(\mathrm{p}=0.017)$.

Conclusion. Most of the medical faculty are aware of the need and have acquired a positive attitude to enforcement of CBME. However significant barriers do exist in the form of manpower and resources which need to be addressed.

\section{Introduction}

Medical curriculum worldwide is experiencing a paradigm shift towards Competency-Based Medical Education (CBME), an outcome-based structure that needs the integration of information, skills, values, and attitudes into observable and measurable competencies. In our country there have been decisive steps in that direction as well ${ }^{[1,2]}$. The need for betterment in medical education is based upon landmark recommendations of the Accreditation Council of Graduate Medical Education of America which mandates the acquisition of six domains of competencies namely, patient care, knowledge, practicebased learning, communication skills, professionalism, and systems-based practice ${ }^{[3-6]}$.

CBME emphasizes a shift from teacher-centered to learner-centered educative methods and a systematic interdisciplinary integrated learning rather than piecemeal information in each department. Another noteworthy alteration is problem-based learning which triggers the scholar to arm himself with knowledge crucial to encounter and solve real-life problems within the hospital or community. Entrustable 
Professional Activities (EPA) are observable and measurable outcomes in CBME which bridges the gap between the idea and practice of technical skills thereby integrating multiple competencies in a holistic nature ${ }^{[7,8]}$. CBME is conducive to the Dreyfus model which emphasizes the medical graduate to travel past five milestones- a novice, advanced beginner, competent, proficient, and expert as a graded transition ${ }^{[9]}$. (Figure.1)

The goal of CBME is to produce an Indian Medical Graduate (IMG) who is envisaged as a doctor fulfilling the roles of clinician, leader, communicator, professional and lifelong learner ${ }^{[10,18]}$ (Table 1). The new regulations on Graduate Medical Education (Amendment), 2019 is more learner-centric, patient-oriented, gender-sensitive, and environment-appropriate leading to an outcome-driven curriculum, in conformity with global trends. To initiate the process of transformation from traditional curriculum into $\mathrm{CBME}$, the teaching faculty of medical institutions need to be sensitized and molded into the modern day medical education facilitators. The National Faculty Development Program (FDP) initiative of the Medical Council of India (MCl) is a step forward in the direction, which aimed to enable and empower faculty of every medical institution across the country by a structured and perpetuating process (Fig. 2).

There has been a steep rise in the number of medical colleges in India from 297 in 2009 (146 within the Government sector and 151 within the private sector) to a total of 554 medical colleges in 2019 (285 within the Government sector and 269 within the private sector) ${ }^{[10-12]}$. In the last 10 years FDP of $\mathrm{MCl}$ had trained 44,932 faculties in Basic Course in Medical Education Technology through 1697 workshops conducted by regional centers and nodal centers. The Curriculum Implementation Support Program (CISP-Phase 1) had been implemented through 557 programs which trained 15,509 faculty in a record time of 7 months ${ }^{[13]}$.

Though FDP's have been in vogue since 2009 till date very little research has gone into assessing the faculty's knowledge and mental preparedness to embrace CBME. Neither has it been evaluated whether the training process has percolated to the grass roots. In this research we aimed to study the existent level of awareness, attitude and perceived barriers towards implementation of CBME among teaching faculty of medical institutes countrywide. 
Table 1

Represents the roles of IMG and new components of GMER 2019

\section{Roles of Indian Medical Graduate with description}

- Clinician - preventive, promotive, curative, palliative and

holistic care with compassion

- Communicator - patients, families, colleagues and community

- Leader -Leader and member of the health care team - collect analyze, synthesize and communicate health data

- Lifelong learner - continuous improvement

- Professional - ethical, responsive and accountable.
New components of Graduate Medical Regulations (GMER) 2019

$\neg$ Foundation course

$\neg$ Early clinical exposure

$\neg$ AETCOM

$\neg$ Self-Directed Learning

$\neg$ Elective posting

$\neg$ Basic research

$\neg$ Problem based learning

$\neg$ Integrated and aligned learning

$\neg$ Reflection and meta-cognition

\section{Materials \& Methods}

This multicentric cross sectional study was conducted among teaching faculty from medical colleges of India. A validated questionnaire was propagated using an online platform [Google forms]. The validation process was done by external expertise. There were 3 sections in the questionnaire- Section A dealt with informed consent of the participants and their socio-demographic data. Those who consented to the study could access the Section B which addressed the awareness of the faculty and Section C investigated attitude and perceived barriers to implementation of CBME in our health system. Only fully completed forms could be successfully submitted. Study period was August 2020 to February 2021. Assuming that $50 \%$ of participants were aware of CBME, minimum sample size needed at $95 \%$ confidence interval and $5 \%$ precision was calcualted using formula $n=z^{2} p q / E^{2}$. Based on this formula sample size required was 178 . Probability sampling method using Stratified Sampling Technique was employed to ensure equitable representation from all segments of medical education like pre, para and clinical departments. All teaching faculty presently serving in Indian Medical Schools were eligible to participate. However only those with a minimum of 2 years of teaching experience were included. Faculty presently on leave for $>6$ months or on psychotropic support or medications were excluded. The study was conducted by the Medical Education Unit members of Government Sivagangai Medical College and Government Villupuram Medical College. The study team regularly scrutinized data collection process and met periodically to review the study conduct and computing of data. At the end of study period, the coded and consolidated data were analyzed using IBM SPSS version 22.

The Section A containing socio-demographic data was analysed using descriptive methods of frequency such as percentage. Internal comparison between faculty of government sector and private sector in awareness about FDP (Section B) and attitude and perceived barriers on CBME (Section C) was done by 
cross tabulation and comparison of percentages. Chi square test was used to test statistical significance [p value $<0.05]$. Descriptive analysis was carried out for assessing the closed response questions about perceived barriers to CBME. The questionnaires are as per Table $2 \& 3$.

\section{Results}

A total of 251 Teaching faculties [200 from Government Institutes and 51 from Private Institutes] completed the questionnaire. The socio-demographic features of participants included age group 25-30 (4.4\%), 31-40 years $(40.6 \%), 41-50$ years $(37.1 \%), 51-60$ years $(17.9 \%)$. Pre, para \& clinical discipline participants were $34.3 \%, 29.1 \%$ and $37.5 \%$ respectively. Among the study sample $188(80.9 \%)$ had undergone at least one FDP, the most common being CISP [Curriculum Implementation Support Program] (Table.2) and their perception of major challenges included high student to faculty ratio (67.7\%), infrastructural deficiencies (41.4\%) and non-feasible assessment methods (41.1\%). The solutions suggested were boosting faculty strength (73.7\%), revamping infrastructure $(69.3 \%)$ performance based remuneration (35.9\%) and additional administrative support (30.7\%) (Table.3).

Internal comparison between government and private medical college faculty revealed a significant increase in FDP attendance by the latter $(p=0.008)$. Furthermore, the groups differed in their ways to overcome barriers of CBME $(p=0.017)$. However, there was no difference in terms of teaching skills, MEU functions, and awareness [Table 2]. 95.2\% agreed that FDP was conducive towards implementing CBME. 
Table 2

Comparison between teaching faculty of government and private sector in FDP awareness

FDP Awareness

Government

Private sector

P-

sector

F $\quad P$

Have you undergone any

Faculty

Development Program

(FDP)?

If no, reason for not

attending

any FDP

Yes

F

$\mathrm{P}$

$142 \quad 71.00 \% \quad 46 \quad 90.20 \%$

No

$58 \quad 29.00 \% \quad 5 \quad 9.80 \%$

(and

Did not get an opportunity

$52 \quad 89.66 \% \quad 3 \quad 60.00 \%$

0.159

Not aware

$\begin{array}{llll}5 & 8.62 \% & 2 & 40.00 \%\end{array}$

No time

$1 \quad 1.72 \% \quad 0 \quad 0.00 \%$

If yes, which of the following

Curriculum

Implementation Support

113

1.72\% $0.00 \%$

FDPs have you undergone?

Program (CISP)

\begin{tabular}{lcccc|}
\hline $\begin{array}{l}\text { Revised Basic Course } \\
\text { Workshop }\end{array}$ & 93 & $65.49 \%$ & 36 & $78.26 \%$ \\
\hline $\begin{array}{l}\text { Attitude Ethics and } \\
\begin{array}{l}\text { Communication } \\
\text { (AETCOM) }\end{array}\end{array}$ & 69 & $48.59 \%$ & 32 & $69.57 \%$ \\
\hline
\end{tabular}

\begin{tabular}{lllll}
\hline Basic Course Workshop & 69 & $48.59 \%$ & 31 & $67.39 \%$ \\
\hline $\begin{array}{l}\text { Advanced Course in } \\
\begin{array}{l}\text { Medical Education } \\
\text { (ACME) }\end{array}\end{array}$ & 25 & $17.61 \%$ & 18 & $39.13 \%$ \\
\hline
\end{tabular}

Foundation for

Advancement of

$3 \quad 2.11 \% \quad 4 \quad 8.70 \%$

International Medical

Education and Research

(FAIMER)

$\begin{array}{lllll}\text { Are you holding any } & 4 & 2.82 \% & 3 & 6.52 \%\end{array}$

other degree in medical

education

Are you aware that a few of the above mentioned FDPs are mandatory for promotion?

\begin{tabular}{lllllll} 
Yes & 186 & $93.00 \%$ & 49 & $96.08 \%$ & 0.536 \\
\cline { 1 - 5 } No & 14 & $7.00 \%$ & 2 & $3.92 \%$ & \\
\cline { 1 - 5 } Agree & 190 & $95.00 \%$ & 49 & $96.08 \%$ & 0.722 \\
\cline { 1 - 5 } Disagree & 6 & $3.00 \%$ & 2 & $3.92 \%$ & \\
\cline { 1 - 5 } Do not know & 4 & $2.00 \%$ & 0 & $0.00 \%$ &
\end{tabular}

Do you agree that FDPs are important to improve teaching skills of medical faculties? 


\begin{tabular}{|c|c|c|c|c|c|c|}
\hline \multirow{3}{*}{$\begin{array}{l}\text { Are you aware of the } \\
\text { existence and functioning of } \\
\text { Medical Education Unit } \\
\text { (MEU) in your institution? }\end{array}$} & $\begin{array}{l}\text { Yes, aware of its } \\
\text { existence, functions \& } \\
\text { activities }\end{array}$ & 164 & $82.00 \%$ & 47 & $92.16 \%$ & \multirow[t]{3}{*}{0.170} \\
\hline & $\begin{array}{l}\text { Yes, aware of its } \\
\text { existence, but not aware } \\
\text { of its functions \& } \\
\text { activities }\end{array}$ & 32 & $16.00 \%$ & 3 & $5.88 \%$ & \\
\hline & $\begin{array}{l}\text { No, not aware of its } \\
\text { existence }\end{array}$ & 4 & $2.00 \%$ & 1 & $1.96 \%$ & \\
\hline \multirow{3}{*}{$\begin{array}{l}\text { Do you agree that FDPs will } \\
\text { be helpful for } \\
\text { implementation of } \\
\text { Competency Based Medical } \\
\text { Education (CBME)? }\end{array}$} & Agree & 193 & $96.50 \%$ & 47 & $92.16 \%$ & \multirow[t]{3}{*}{0.107} \\
\hline & Disagree & 2 & $1.00 \%$ & 0 & $0.00 \%$ & \\
\hline & Do not know & 5 & $2.50 \%$ & 4 & $7.84 \%$ & \\
\hline \multirow{2}{*}{$\begin{array}{l}\text { Are you interested in } \\
\text { attending all the FDPs? }\end{array}$} & Yes & 183 & $91.50 \%$ & 44 & $86.27 \%$ & \multirow[t]{2}{*}{0.295} \\
\hline & No & 17 & $8.50 \%$ & 7 & $13.73 \%$ & \\
\hline
\end{tabular}


Table 3

Comparison between teaching faculty of government and private sector in attitude and perceived barriers on CBME.

\begin{tabular}{|c|c|c|c|c|c|c|}
\hline \multicolumn{2}{|c|}{ Attitude and perceived barriers on CBME } & \multicolumn{2}{|c|}{ Government } & \multicolumn{2}{|c|}{ Private } & \multirow{2}{*}{$\begin{array}{l}\mathrm{P} \text { - } \\
\text { value }\end{array}$} \\
\hline & & $\mathbf{F}$ & $\mathbf{P}$ & $F$ & $\mathbf{P}$ & \\
\hline \multirow{2}{*}{$\begin{array}{l}\text { Are you aware of CBME being } \\
\text { implemented by NMC in a } \\
\text { phased manner? }\end{array}$} & Yes & 183 & $91.50 \%$ & 49 & $96.08 \%$ & \multirow[t]{2}{*}{0.360} \\
\hline & No & 17 & $8.50 \%$ & 2 & $3.92 \%$ & \\
\hline \multirow{3}{*}{$\begin{array}{l}\text { If yes, do you think it can be } \\
\text { effectively implemented in } \\
\text { your institution? }\end{array}$} & Yes & 140 & $76.50 \%$ & 34 & $69.39 \%$ & \multirow[t]{3}{*}{0.461} \\
\hline & Partly & 42 & $22.95 \%$ & 15 & $30.61 \%$ & \\
\hline & No & 1 & $0.55 \%$ & 0 & $0.00 \%$ & \\
\hline \multirow[t]{2}{*}{ In your opinion, CBME is } & $\begin{array}{l}\text { Is a positive step } \\
\text { forward in improving } \\
\text { the present system of } \\
\text { medical education }\end{array}$ & 190 & $95.00 \%$ & 49 & $96.08 \%$ & \multirow[t]{2}{*}{1.000} \\
\hline & $\begin{array}{l}\text { Is a wasteful exercise } \\
\text { without much } \\
\text { productivity }\end{array}$ & 10 & $5.00 \%$ & 2 & $3.92 \%$ & \\
\hline \multirow{9}{*}{$\begin{array}{l}\text { Which according to you are the } \\
\text { main changes in Graduate } \\
\text { Medical Education Regulations } \\
\text { 2019? }\end{array}$} & Early clinical exposure & 162 & $81.00 \%$ & 47 & $92.16 \%$ & \multirow[t]{9}{*}{0.511} \\
\hline & Integrated teaching & 164 & $82.00 \%$ & 45 & $88.24 \%$ & \\
\hline & Foundation course & 164 & $82.00 \%$ & 43 & $84.31 \%$ & \\
\hline & Self-directed learning & 153 & $76.50 \%$ & 45 & $88.24 \%$ & \\
\hline & AETCOM module & 148 & $74.00 \%$ & 41 & $80.39 \%$ & \\
\hline & Elective posting & 132 & $66.00 \%$ & 39 & $76.47 \%$ & \\
\hline & Basic research & 127 & $63.50 \%$ & 31 & $60.78 \%$ & \\
\hline & $\begin{array}{l}\text { Reflection and meta- } \\
\text { cognition }\end{array}$ & 92 & $46.00 \%$ & 28 & $54.90 \%$ & \\
\hline & $\begin{array}{l}\text { Problem based } \\
\text { learning }\end{array}$ & 33 & $16.50 \%$ & 19 & $37.25 \%$ & \\
\hline \multirow{4}{*}{$\begin{array}{l}\text { In your experience /perception } \\
\text { in what aspects have you } \\
\text { faced / expect to face } \\
\text { challenges in implementation } \\
\text { of CBME? }\end{array}$} & $\begin{array}{l}\text { Issues involving } \\
\text { faculty }\end{array}$ & 132 & $66.00 \%$ & 38 & $74.51 \%$ & \multirow[t]{4}{*}{0.969} \\
\hline & $\begin{array}{l}\text { Issues involving } \\
\text { infrastructure }\end{array}$ & 83 & $41.50 \%$ & 22 & $43.14 \%$ & \\
\hline & $\begin{array}{l}\text { Issues involving } \\
\text { assessment }\end{array}$ & 78 & $39.00 \%$ & 26 & $50.98 \%$ & \\
\hline & $\begin{array}{l}\text { Issues involving } \\
\text { curriculum }\end{array}$ & 61 & $30.50 \%$ & 17 & $33.33 \%$ & \\
\hline
\end{tabular}


Issues involving students

In your opinion the most important step to facilitate CBME implementation is:

colleges
$54 \quad 27.00 \% \quad 16 \quad 31.37 \%$

Increase the faculty numbers in medical

148

$74.00 \%$

37

$72.55 \%$

\begin{tabular}{lcccc}
$\begin{array}{l}\text { Improve the } \\
\text { infrastructure for } \\
\text { teaching learning } \\
\text { methods }\end{array}$ & 136 & $68.00 \%$ & 38 & $74.51 \%$ \\
\hline $\begin{array}{l}\text { Provide extra } \\
\text { remuneration to } \\
\text { existent faculty }\end{array}$ & 66 & $33.00 \%$ & 24 & $47.06 \%$ \\
\hline $\begin{array}{l}\text { Ensure political and } \\
\text { administrative will to } \\
\text { achieve results. }\end{array}$ & 48 & $24.00 \%$ & 29 & $56.86 \%$ \\
\hline
\end{tabular}

Table 4

Perceived problems and suggested solutions for implementation of CBME by faculties.

\section{Perceived problems Perceived solutions}

\section{Challenges for faculty}

- Lack of awareness

Motivation and sensitization programs with feedback evaluation

- Disinterest

- Promotion /Incentives

- Lack of guidance

- MEU and inter department cooperation

- Frequent transfers

- Increased faculty training

- Increased student

- Optimization of student to faculty ratio, and training the junior residents :patient ratio and interns.

\section{Challenges with infrastructure and administrations}

- Poorly developed MEU

- Lack of administrative support
- MEU strengthened as per NMC norms and sensitization of administrative staff

- Dedicated faculty, paramedical staff should posted for medical education department

\section{Challenges with students \& assessment}

- Lack of students awareness of CBME

- Lack of uniformity in assessment
- Students need to be trained and sensitized about new curriculum with feedback evaluation and re-evaluation.

- Mentorship program needs to implemented.

- National wide universities coordination for assessments

\section{Discussion}


Indian medical education system, one of the largest in the world is under the process of transforming itself into a structured and globally relevant principle ${ }^{(14)}$. Some of the hallmark alterations in the present curriculum include incorporation of androgogical teaching methods like Self Directed Learning [SDL], cooperative learning, small group teaching, community practices, special emphasis on formative assessment and wholesome acquisition of skills to function as part of the health care team. Such landmark reforms in education system is possible only if the medical educator understands and embraces the concept of CBME. This sets into motion the chain of events finally culminating in an education system on par with international standards. Faculty Development Programs are crucial first steps fueling the evolution of modern day medical education facilitators.

In our study pre, para, and clinical faculties participated in adequate numbers to be representative of their respective fields. The majority were of the cadre of Assistant Professor, Associate Professor and Professor. In our study the government faculty outnumbered those from private institutes probably because the authors were from government sector and better identified among the same population.

Previous research by Rustagi SM et al. identified that $44.8 \%$ faculties had undergone RBCW and $39.7 \%$ attended CISP [15]. Appreciably we documented $64.5 \%$ RBCW trained and $74.9 \%$ trained in CISP which is encouraging and a significant improvement over the former record. The remaining faculty quote lack of opportunity as reason behind the lapse presumably due to heavy work burden. Nevertheless $93.6 \%$ are still aware that RBCW has been made mandatory for consideration for promotion in ranks. This leaves a large lacuna to be filled and is at the behest of the administrative heads to create opportunities for all.

The Medical Education Units of medical schools play a pivotal role in organizing FDP for all faculties. In this regard, it was reassuring to find that $84.1 \%$ of participants were well aware of the structure and functions of MEU [Table 2] and $95.2 \%$ strongly agreed to the crucial role of FDP in implementing CBME. An appreciable fraction [> 70\%] of the study responders remained updated about the newer components of Graduate Medical Education Regulations most notably, the foundation course, early clinical exposure, integrated teaching, AETCOM module and Self Directed Learning [SDL]. In comparison with the report by Rustagi SM et al, our observations were far more encouraging. The former had recorded only $12.9 \%$ faculty awareness about curriculum and $56.9 \%$ negative attitude towards CBME.

Reforms in the educational field are fraught with challenges and impediments. Truthfully so, research findings by Kulkarni et al in 2020 found that student to faculty ratio, poor infrastructure, time constraints, lack of commitment and human inertia to be the main hurdles in the way of CBME ${ }^{[16,18]}$. Our findings mirrored similar reflections among the faculty as depicted in Table 4. To highlight a few, demotivation, fatigue among faculties, lack of administrative support and non uniformity in assessment methods were perceived as significant barriers to implement the new curriculum ${ }^{[17]}$. The mindset $\&$ attitude of teachers accustomed to the traditional curriculum has to change if CBME aims to spread roots into the system. Hearteningly we found that majority of our participants (95.2\%) housed a positive attitude and were willing to walk the tight rope to enforce reforms. 
The authors stand to understand that though there are quite a few impediments en route to full operationalization of $\mathrm{CBME}$, the stakeholders are conducive and the transformation has long begun. However we recommend that politically committed administrative support and feedback evaluation from faculty and students be given due weightage to ease out the wrinkles of the system.

\section{Limitation}

The major limitation of this study was its sample size. We conducted the study during the peak phase of COVID 19 pandemic which probably evoked a less optimal response from the participants. Though the minimum appropriate sample size as per statistical formula was achieved a larger sample would definitely have been more informative. Another drawback was a thin representation from the private sector institutes. The authors being from government run institutions couldn't evoke a more energetic response from their counterparts in the other sector.

\section{Conclusion}

There is an existing favorable environment for change from traditional curriculum to CBME. Most of the faculty of medical institutes across the country are aware of the need and have acquired a positive attitude to enforce the educational reform. Significant barriers do exist however in the form of manpower and resources which need to be addressed by political commitment and administrative spearheading.

\section{Declarations}

Financial support \& sponsorship: None.

Conflicts of interest: None.

\section{Abbreviations}

FDP - Faculty Development Programme

CBME - Competency Based Medical Education

IMG - Indian Medical Graduate

GMER - Graduate Medical Education Regulations

AETCOM - attitude and communication

CISP - Curriculum Implementation Support Program

SDL - Self Directed Learning 
ACME - Advanced Course in Medical Education

FAIMER - Foundation for Advancement of International Medical Education and Research

\section{References}

1. Frank JR, Snell LS, Cate OT, Holmboe ES, Carraccio C, Swing SR, Harris P., Glasgow NJ, Campbell C, Dath D, Harden RM. Competency-based medical education: theory to practice. Medical teacher. 2010; 32(8):638-45.

2. Faculty Development for Competency Based Medical Education, Payal Bansal, Avinash Supe NJIRM 2017; Vol. 8(5) September - October eISSN: 0975-9840 pISSN: 2230 - 9969

3. Swing SR. The ACGME outcome project: Retrospective and prospective. Med Teach. 2007;29:64854. [PubMed: 18236251]

4. General Medical Council. Tomorrow's Doctors: Education Outcomes and Standards for Undergraduate Medical Education. [Last accessed on 2016 May 16]. Available from: http://www.gmc-uk.org/Tomorrow_s_Doctors_1214.pdf_48905759.pdf .

5. Frank JR, Danoff D. The CanMEDS initiative: Implementing an outcomes-based framework of physician competencies. Med Teach. 2007;29:642-7. [PubMed: 18236250]

6. Modi JN, Gupta P, Singh T. Competency-based medical education, entrustment and assessment. Indian Pediatr 2015;52:413-20

7. Ten Cate O. Nuts and bolts of entrustable professional activities. J Grad Med Educ. 2013;5:157-8. [PMCID: PMC3613304] [PubMed: 24404246]

8. Ten Cate O, Scheele F. Competency-based postgraduate training: Can we bridge the gap between theory and clinical practice? Acad Med. 2007;82:542-7. [PubMed: 17525536]

9. Batalden P, Leach D, Swing S, Dreyfus H, Dreyfus S. General competencies and accreditation in graduate medical education. Health Aff (Millwood) 2002;21:103-11. [PubMed: 12224871]

10. Medical Council of India. College and Course search. Available at https://www.mciindia.org/CMS/information-desk/college-and-course-search Accessed Apr 15, 2018.

11. Information Desk, Course and colleges list, National Medical Commission.

12. Mahajan R, Badyal DK, Singh T. Online Faculty-Development Programme for Medical Teachers in Resource Poor Settings: Behind the Scene. J Res Med Edu Ethics 2017;7:163-168.

13. Medical Council of India. Curriculum Implementation Support Program (CISP I): First year Report 2019 (pp. 1- 49).

14. Deswal BS, Singhal VK. Problems of medical education in India. Int JCommunity Med Public Health 2016;3:1905-9. DOI: http://dx.doi.org/10.18203/2394-6040.ijcmph20162063

15. Rustagi SM, Mohan C, Verma N, et al. Competency-based Medical Education: The Perceptions of Faculty. J Med Acad 2019;2(1):1-5. 
16. Kulkarni P, Pushpalatha K, Bhat D. Medicaleducation in India: Past, present, and future. APIK J Int Med 2019;7:69-73. 10.4103/AJIM.AJIM_13_19.

17. Caverzagie KJ, Nousiainen MT, Ferguson PC, Ten Cate O,Ross S, Harris KA, et al. Overarching challenges to the implementation of competency-based medical education. Med Teach 2017;39:588-93

18. Herur A, Kolagi S. Competency-based medical education: Need of the hour: Let's do our bit...!!. BLDE Univ J Health Sci 2016;1:59-60. DOI:10.4103/2456-1975.183292

\section{Figures}

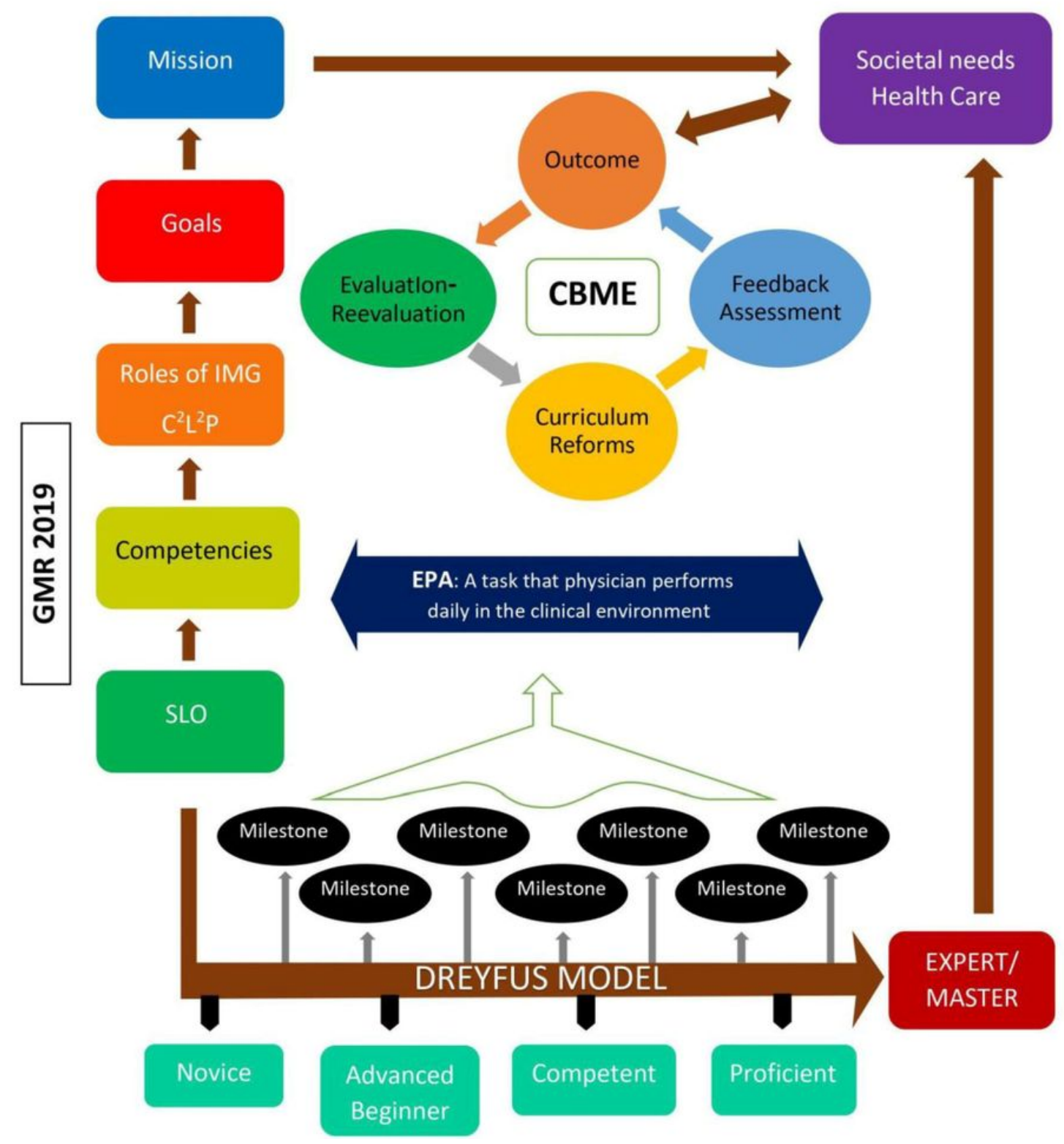


Figure 1

shows link between Graduate Medical Regulations 2019 and societal need C2L2P:Clinician ,communicator, life long learner,leader,professional

\section{National Medical council Team}

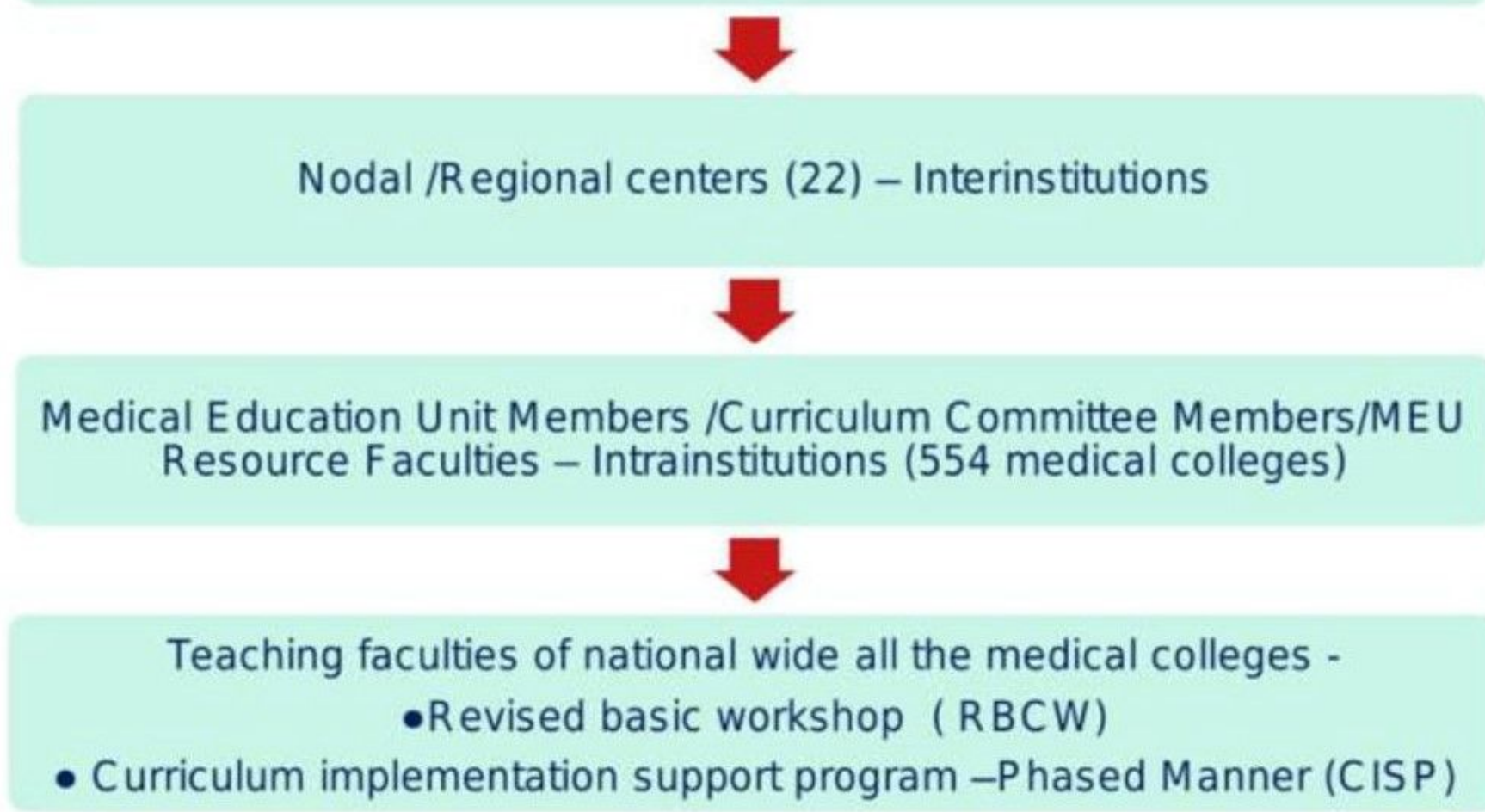

Figure 2

shows rollout plan for the implementation of CBME in India. 


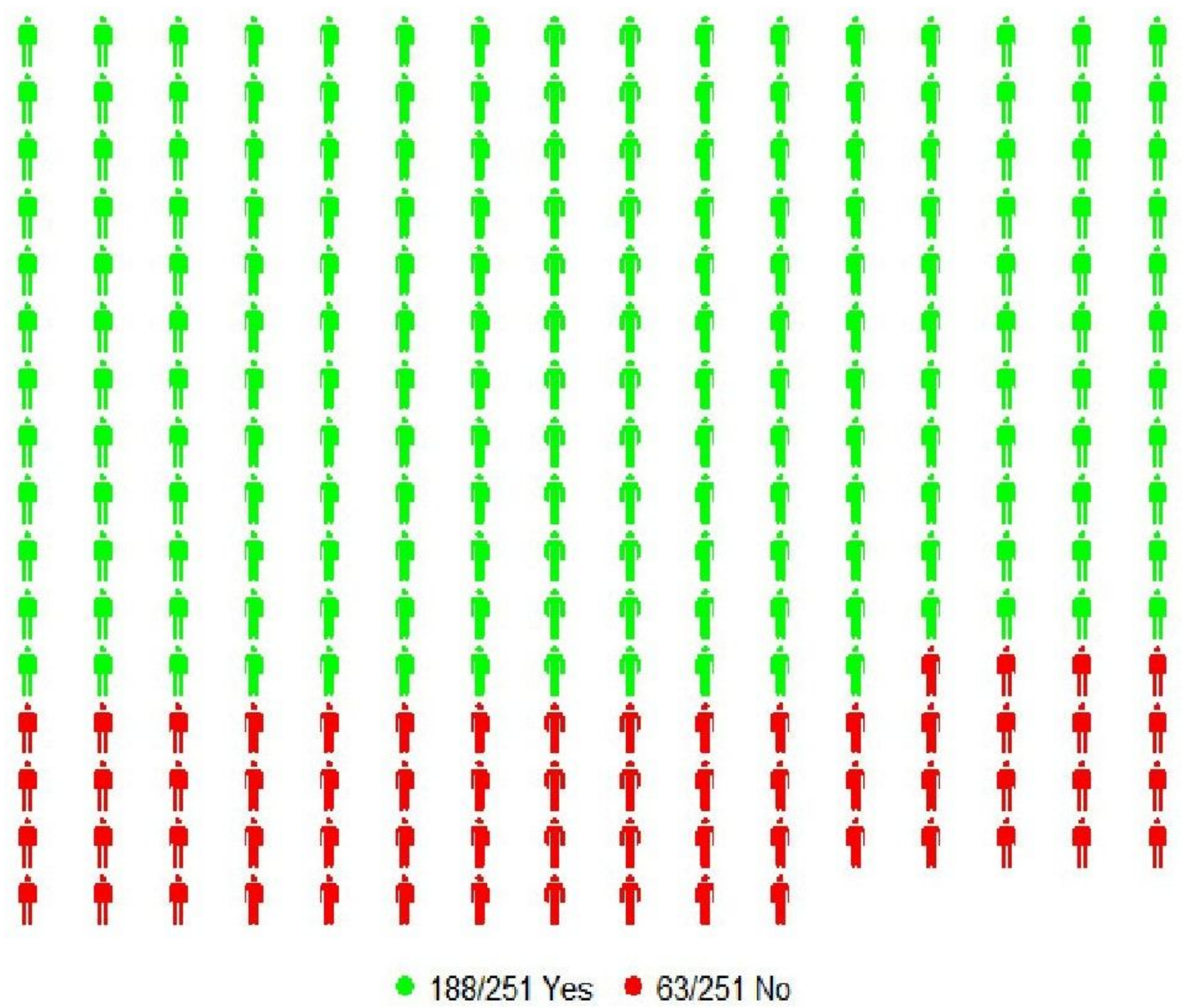

Figure 3

Pictogram showing number of participants undergone Faculty Development Programme $(\mathrm{N}=251)$ 